\title{
Improvement of English Communication Ability With Virtual Scenes Based on Electronic Schoolbag
}

\author{
https://doi.org/10.3991/ijet.v16i13.24041 \\ Lingling $\mathrm{Hu}$ \\ Zhengzhou Normal University, Henan, China \\ zzmail20@163.com
}

\begin{abstract}
In the context of global integration, there is a growing need for talents who master English, the lingua franca, and excel in English communication. Therefore, an important goal of English teaching is to enhance the students' ability to communicate in English. After analyzing the ideas and principles of applying virtual scenes based on electronic schoolbag (eschoolbag), this paper established an e-schoolbag model with several function modules, and created virtual scenes that seamlessly connect with actual scenes. Next, a questionnaire survey was carried out on students' English communication ability, and virtual scenes were designed based on e-schoolbag for English teaching. Finally, a comparative analysis was conducted to verify if the e-schoolbag-based virtual scenes can improve students' ability to communicate in English. The results showed that the main problems of English teaching are the lack of diverse teaching methods, the boring teaching contents, and the overemphasis on examination; students are not good at English communication, due to the absence of a suitable linguistic environment; the eschoolbag-based virtual scenes can provide students with a favorable linguistic environment, arouse their interests in learning English communication, and significantly improve their English communication ability.
\end{abstract}

Keywords-Electronic schoolbag (e-schoolbag), virtual scenes, English teaching; English communication ability

\section{Introduction}

Language is a tool for people to exchange their ideas and emotions. However, under the traditional exam-oriented education mode, in China, the cultivation of English communication ability has long been neglected during the English teaching, and the phenomenon of "dumb English" is quite common due to the lack of a good linguistic environment. In recent years, with the apid progress of education informatization, the new English curriculum standards in China have imposed new requirements for English teaching, and "developing students' comprehensive language ability" is one of them, in such context, the e-schoolbag has provided a new opportunity for students' English learning and the cultivation of their English communication ability. 
The original design purpose of e-schoolbag is to digitize the paper teaching resources such as textbooks, exercises, and extracurricular reading materials that are necessary for students' learning, and store them in portable terminals, thereby reducing the weight of students' schoolbags [1]. With the rapid development of cloud computing and Internet technology, the functions of the e-schoolbag are enriched gradually. When modeling the e-schoolbag, Korean scholars paid more attention to the interaction, multimedia, and educational nature of the e-schoolbag, and they had added a few new functions such as 3D graphics, audio-video education, navigation, and search; teachers can use the electronic blackboards installed in classrooms to call out the digital textbooks, and students can obtain various e-learning materials through the cloud system [2]. With the help of e-schoolbag, teachers can prepare lessons before class and restore teaching scenarios in the class, while students can preview the lessons before class and discuss with teachers about questions they have with the lessons, after class, students can study at anywhere anytime, and communicate with teachers at will through the e-schoolbag. However, due to the insufficient research on student information management and other services, the application effect of eschoolbag is not ideal [3]. In France, the e-schoolbag function models were established using the method of virtual collaborative working space, they are mainly used to support group activities, however, due to the lack of research on the materials and tools, they could not meet the actual teaching requirements, either [4]. In China, Taiwan has established the e-schoolbag-based free classroom system the e-schoolbag system, and the two systems can provide support for teachers and students to perform teaching activities anytime and anywhere [5]. Teacher Zhu Zhiting introduced a variety of teaching aids and learning tools to improve the utilization of third-party teaching resources; based on the "service platform + mobile terminal + educational content" pattern, Zhu constructed an e-schoolbag model with comprehensive functions, but it's not sure whether it can support interaction outside the class [6]. After reviewing previous literatures, it's found that the domestic and foreign studies have obtained rich research results on e-schoolbag and its related technologies, but there're quite a few shortcomings, and there are few research results on the virtual scenes based on eschoolbag technology.

Based on above analysis and previous research results, aiming at improving students' English communication ability, this paper designed virtual scenes for the application of e-schoolbag, and constructed the e-schoolbag-based virtual scene English teaching model; then, through comparative analysis, the proposed model was verified to have a significant effect on improving students' English communication ability.

\section{Design of the Virtual Scenes for the Application of $\mathrm{E}$ - Schoolbag}

\subsection{Design and analysis of the virtual scenes}

Design ideas: The virtual scenes for the application of e-schoolbag were designed based on the following three design ideas: 
1. In terms of application design, the virtual scenes should form an intelligent partnership with the students, act as participants and promoters, and become the best intelligent combination with learners [7].

2. In terms of providing services, after data analysis, the virtual scenes based on eschoolbag technology should be able to push services and scenes that are related to students' learning situations, interests, and hobbies according to their use habits and learning conditions, thereby realizing all-round and multi-level associations and recommendations [8].

3. In terms of learning experience: attentions should be paid to the emotional experience and psychological needs of learners during the learning process, learners' individual needs should also be taken into consideration to create learning tools with unique features for learners, such as the appearance setting of the virtual scenes [9].

\section{Design principles}

Integrate virtual scenes with teaching materials: With the progress of education reform, the cultivation of students' comprehensive English ability has become the focus of English teaching, therefore, in the English textbooks, a lot of English practice activities with students as the dominant party have been designed. For the e-schoolbagbased virtual scenes, the corresponding scenes should be created with the teaching materials as the basis, so that students can practice and use the English knowledge they learned in the virtual scenes, and deepen their understanding and mastery of the English language.

Virtual scenes are consistent with real life: Use virtual scenes to create a real, natural, and life-like simulated communication environment for students, and solve the long-standing problem that the English learning lacks the verbal communication environment from both aspects of internal demands and external incentives. After students enter the created virtual scenes, they will spontaneously communicate in English under the influence of non-verbal factors such as the virtual characters' actions and expressions, and the streets and shops in the scenes, as well as the verbal factors such as the language of the characters in the scenes, in this way, they can master the specific meanings of the words and sentences, understand the language, and have the encourage to use the language [10].

Integrate classroom teaching with extracurricular activities: The teaching time of English classes is limited. After students learnt English knowledge in the class, they need to find the corresponding language environment to use and consolidate the knowledge they learnt and to improve their English communication ability. Therefore, the virtual scenes should be created based on the classroom teaching content, providing students with a virtual environment with diverse extracurricular activities, so that students can apply what they have learned.

Pay attention to learners' characteristics: The virtual scenes should be created based on students' personality characteristics, the law of cognition, and the law of language learning. With cultivating students' interests in English learning and gaining a sense of success in English learning as the goals, game-like virtual scenes and display-style virtual scenes should be created to enable students to experience the fun of 
English learning while improving their English communication ability at the same time [11].

\subsection{Function modules of the e-schoolbag}

Teachers, students, services, management, tools, and resources are the main elements in the function modules of e-schoolbag model [12]. From the perspective of teaching requirement, this paper constructed an e-schoolbag model based on the functions of each element in e-schoolbag, the model contains four modules, as shown in Figure 1.

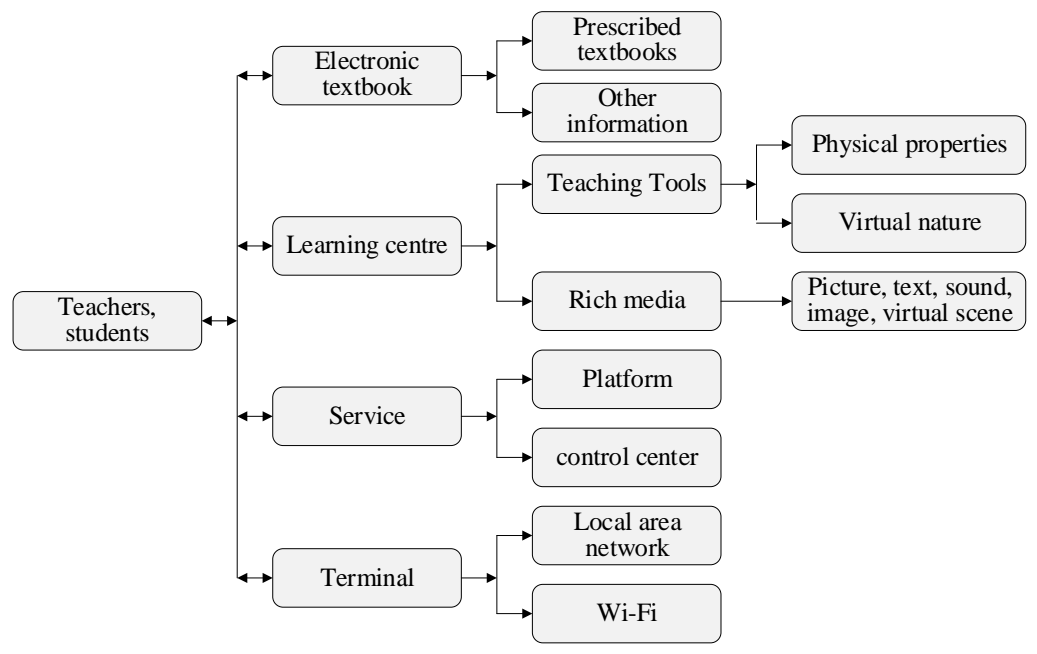

Fig. 1. Function modules of e-schoolbag

Electronic textbooks: The electronic textbooks should be in line with the specified textbooks and related supplementary materials in the teaching syllabus, besides, students can obtain third-party digital learning resources related to the teaching content through the e-schoolbag, such as the resources of high-quality courses of other schools.

Service: The service module consists of three parts. The first part is the control center, its main function is to store relevant information of teachers and students. Teachers can use control center to assign learning tasks to students, distribute learning resources, manage students' exam scores, and monitor students' learning situations using the e-schoolbag, including the time of use, preview, homework completion, and other materials related to students' learning, in this way, teachers can better design and instruct the teaching. The second part is the platform. The interactive platform provides an environment for the communication between teachers and students. In class, teachers can use the interactive platform to raise questions and check students' answers, and students can use it to communicate with teachers and other students about the questions; after class, teachers and students can also communicate in other 
forms such as leaving messages, Q\&A, and online chatting. The third part is thirdparty support service. Students and teachers can use the service provided by a third party to deliver the learning resources, and search and learn the relevant knowledge [13].

Learning center: Learning center is the core part of e-schoolbag. Students and teachers use the learning center module to complete pre-class preparation and preview, in-class teaching and discussion, and after-class review and practice. Learning center is composed of two parts: teaching tools and rich media. The virtual teaching and learning tools are mainly to digitize the traditional paper textbooks [14-19], and the rich media are sub-divided into four parts: images, texts, audios, and videos. With the help of this module, the teaching contents can be displayed for students in the forms of images, texts, audios, and videos more vividly, and it can enrich students' audiovisual experience, and inspire their interest; at the same time, this part can create virtual scenes that seamlessly connect the real scenes so that the teaching activities can be carried out in the corresponding teaching scenes to improve the teaching efficiency. After class, students can also choose virtual scenes that are similar to the teaching content for review, or use the English knowledge they learnt in the entertainment English communication scenes provided by the created virtual scenes, such as English speeches, English dubbing, English KTV, and English games, etc., in this way, students' English communication ability could be improved. Figure 2 shows an oral English exercise scene in a virtual restaurant, students can use such virtual scenes for their after-class review or practice, and they can choose different roles for waiters and dinners according to the personalized circumstances.

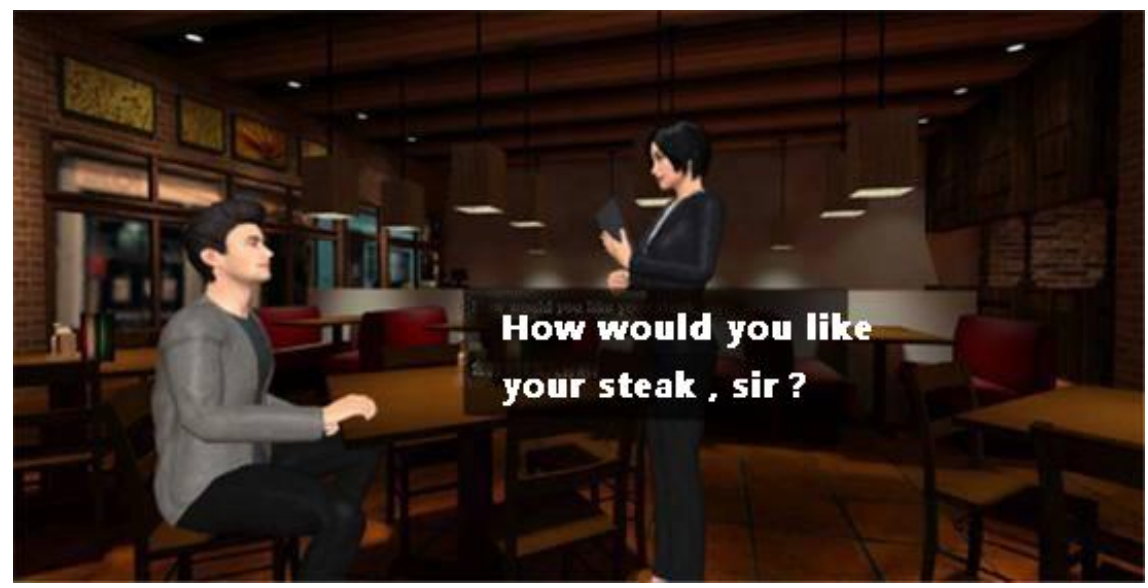

Fig. 2. Virtual scene for taking order at a restaurant

Terminal: The terminal module is the e-schoolbag used by students, through wireless network or local area network, it can achieve teacher-student communication and data transmission. 


\section{Impact of E-Schoolbag-Based Virtual Scenes on the Improvement of English Communication Ability}

\subsection{Survey on students' English communication ability}

In order to investigate the impact of e-schoolbag-based virtual scenes on the improvement of students' English communication ability, this study took a few junioryear students from a university as the research objects and adopted questionnaire survey and interviews to investigate current students' English communication ability, the specific results are as follows:

Figure 3 shows the survey results on whether the respondents think English communication ability is important or not, according to the figure, students who think English communication ability is very important or important accounted for $76 \%$, indicating that most of them have realized the importance of English communication ability, knowing how to use English to exchange and communicate is one of the main purposes of English learning.

Figure 4 shows the statistics on whether the respondents are interest in improving their English communication ability, according to the figure, although more than half $(57 \%)$ of the students expressed that they are very interested in or interested in improving their English communication ability, still $43 \%$ of them said they are not very interested or not interested at all. Further analysis of the interview results suggested that some students are unwilling to improve their English communication ability because they think English learning is boring and tedious, or even if they have learnt English, they seldom have the opportunity to communicate or exchange with others in English; moreover, some students are embarrassed to communicate with others in English because they don't know whether they say it right or not, and they are afraid that others may laugh at them.

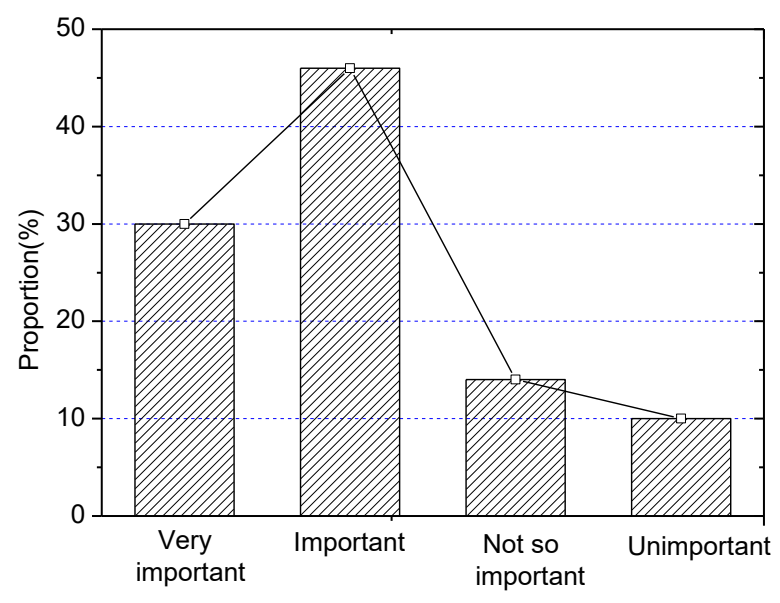

Fig. 3. Opinions of respondents on whether English communication ability is important 


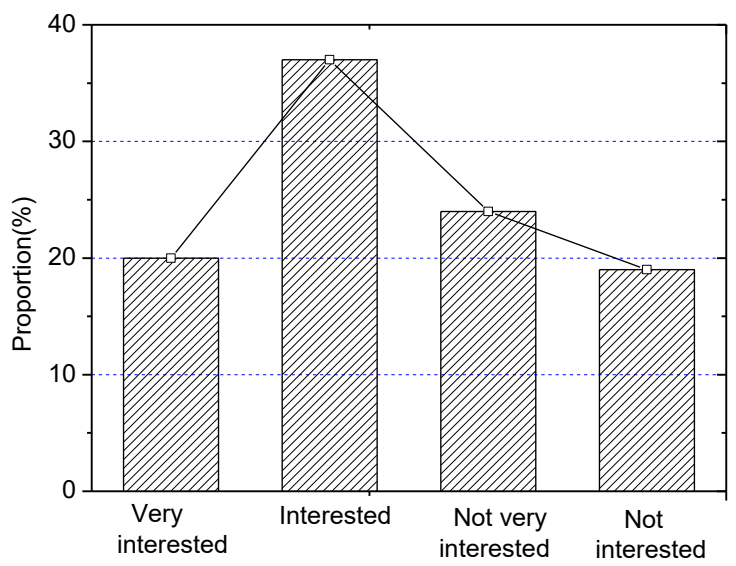

Fig. 4. Statistics on whether the respondents are interest in improving English communication ability

Figure 5 shows the statistics on whether the respondents' English teachers pay attention to the cultivation of students' English communication ability, according to the figure, about 32\% of the English teachers do not pay much attention to the cultivation of students' English communication ability during English teaching, and 6\% of them do not pay attention; further analysis showed that these teachers only pay attention to the explanation of vocabularies and grammar when teaching, their teaching method is exam-oriented, and their explanations are mainly in Chinese. Teachers who pay great attention or more attention to the cultivation of students' English communication ability accounted for $17 \%$ and $45 \%$, respectively, and these teachers mostly use two languages in their teaching, sometimes they would ask students in English and ask them to answer and raise questions in English.

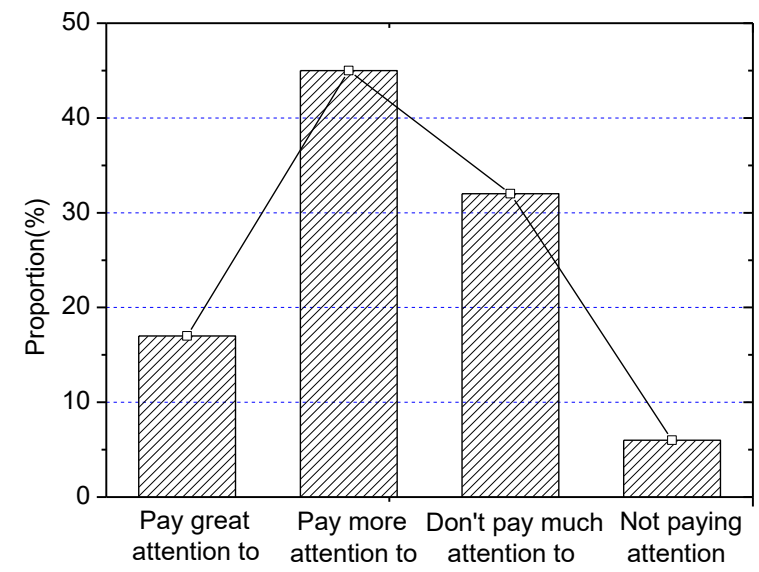

Fig. 5. Statistics on whether the respondents' English teachers pay attention to the cultivation of students' English communication ability 
Survey results indicated that currently the students and teachers do have a certain understanding of the importance of English communication ability, but due to the long-term influence of the traditional exam-oriented education mode, there're certain problems such as the monotonous teaching method, dull content, and exam-centered, in addition, due to the absence of a suitable language environment, current students' English communication ability is worrisome.

\subsection{The virtual scene English teaching mode based on e-schoolbag}

According to the current situation of students' English communication ability and the characteristics of the e-schoolbag technology, this study divided the virtual scene English teaching mode into three stages: before-class, in-class, and after-class, as shown in Figure 6.

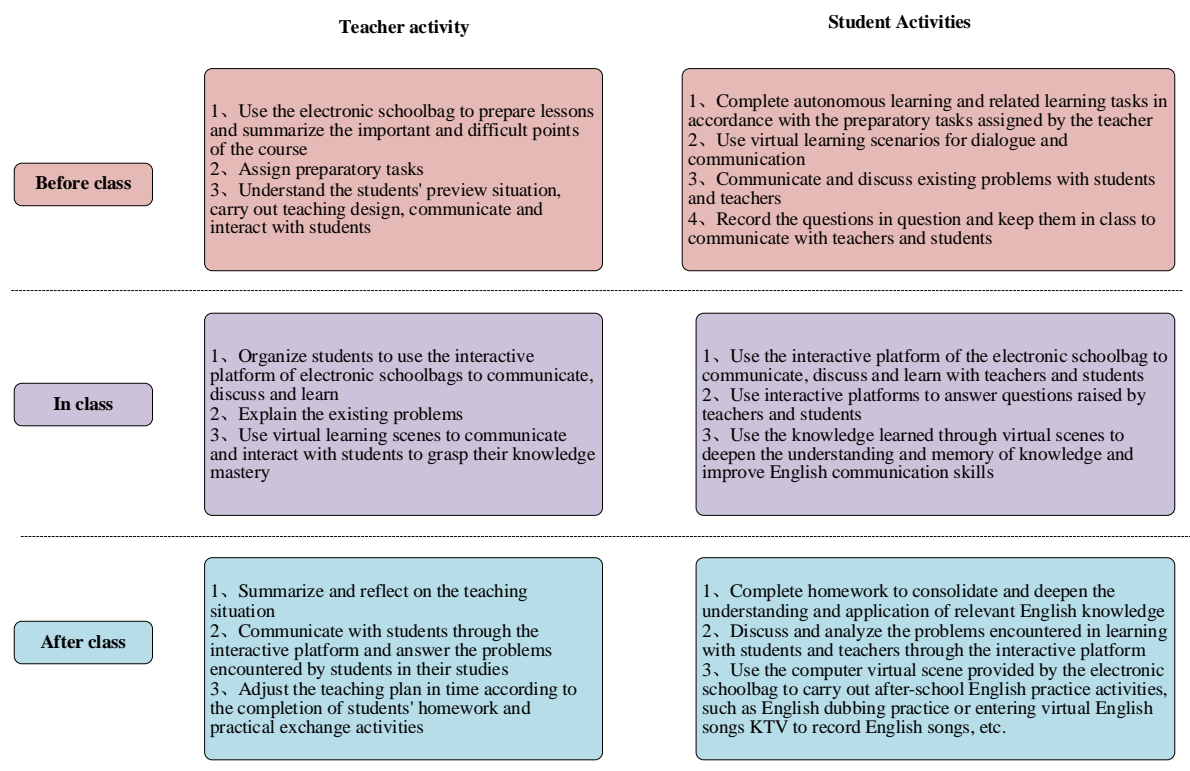

Fig. 6. The virtual scene English teaching mode based on e-schoolbag

\subsection{Application effect of the e-schoolbag-based virtual scene teaching mode}

Methodology: To figure out whether the e-schoolbag-based virtual scene teaching mode has a promotive effect on improving students' English communication ability, this study selected two non-English major classes from the third-grade of a university as the research objects, there're 45 students in each class, one class was taken as the test group to carry out teaching using the e-schoolbag-based virtual scene teaching mode, and the other class was taken as the control group to adopt the traditional classroom English teaching mode. The test time was one semester, the pre-test and posttest scores of the test group and the control group were compared to evaluate students' 
ability in English communication. The evaluation on the English communication ability is mainly to test and assess the English-speaking ability among the four types of English ability (listening, speaking, reading, writing), therefore, based on related research results, a set of English communication ability evaluation criteria was designed, and the evaluation had three parts, namely English dialogue, English oral composition, and English material reading. In order to eliminate interference from other factors, the two classes were taught by a same teacher, and the dialogue topics, the English oral composition topics and the English reading materials used by the two groups were the same, their performance was scored by a same group of evaluators (3 teachers), and average scores were taken as the final results. The full score for each part was 10 points. Table 1, Table 2, and Table 3 respectively list the scoring standards for English dialogue, English oral composition, and English material reading.

Table 1. Scoring standards for English dialogue

\begin{tabular}{|l|c|}
\hline \multicolumn{1}{|c|}{ Grading criterion } & Score \\
\hline $\begin{array}{l}\text { Express clearly, appropriate pronunciation and speaking speed, fluent sentences, and use rich } \\
\text { vocabulary }\end{array}$ & 3 \\
\hline $\begin{array}{l}\text { Appropriate language, correct structure, conforming to specifications, clear and accurate pronunci- } \\
\text { ation, natural intonation, and correct grammar }\end{array}$ & 3 \\
\hline Can expand around topics, prominent main content, rich description & 2 \\
\hline $\begin{array}{l}\text { The dialogue is complete and effective, able to introduce topics and answer topics freely in a } \\
\text { timely manner }\end{array}$ & 2 \\
\hline
\end{tabular}

Table 2. Scoring standards for English oral composition

\begin{tabular}{|l|c|}
\hline \multicolumn{1}{|c|}{ Grading criterion } & Score \\
\hline $\begin{array}{l}\text { The voice and intonation are very authentic, the words and sentences are appropriate and natural, } \\
\text { with rendering power, and strong expressive power }\end{array}$ & $9-10$ \\
\hline $\begin{array}{l}\text { The voice intonation is relatively standardized, conforms to the English expression habits, the } \\
\text { content is rich, the volume is normal, confident and generous, }\end{array}$ & $7-8$ \\
\hline $\begin{array}{l}\text { The voice intonation is plain, with 1-2 grammar and vocabulary errors, the content is relatively } \\
\text { rich, the volume is low or too nervous and not smooth }\end{array}$ & $5-6$ \\
\hline $\begin{array}{l}\text { There are problems with pronunciation and intonation, but it does not affect comprehension. There } \\
\text { are 3-4 grammatical and vocabulary errors, and the content is not rich enough }\end{array}$ & $3-4$ \\
\hline $\begin{array}{l}\text { There are serious problems with pronunciation and intonation, which affects comprehension. There } \\
\text { are more than 5 grammatical and vocabulary errors and less content }\end{array}$ & $1-2$ \\
\hline Unable to organize verbal answers or do not understand what is expressed at all & 0 \\
\hline
\end{tabular}

Table 3. Scoring standards for English material reading

\begin{tabular}{|l|l|c|}
\hline Evaluation item & \multicolumn{1}{|c|}{ Grading criterion } & Score \\
\hline Intonation & $\begin{array}{l}\text { The pronunciation is correct, the pronunciation and intonation are standard and } \\
\text { standardized, and there is charm }\end{array}$ & 3 \\
\hline Skill level & $\begin{array}{l}\text { Appropriate speaking speed, natural, smooth, without repetition, without inter- } \\
\text { ruption }\end{array}$ & 3 \\
\hline Content & Accurate, no additions, no omissions & 2 \\
\hline $\begin{array}{l}\text { Deportment } \\
\text { emotion }\end{array}$ & The facial expressions are natural and decent, full of emotions, and contagious & 2 \\
\hline
\end{tabular}


Evaluation results of English communication ability: Figure 7 shows the evaluation results of the English communication ability of research objects in the test group and control group before the experiment. According to the figure, before the experiment, the English communication ability of the test group and the control group was basically in the same level, which had indicated the effectiveness of the samples.

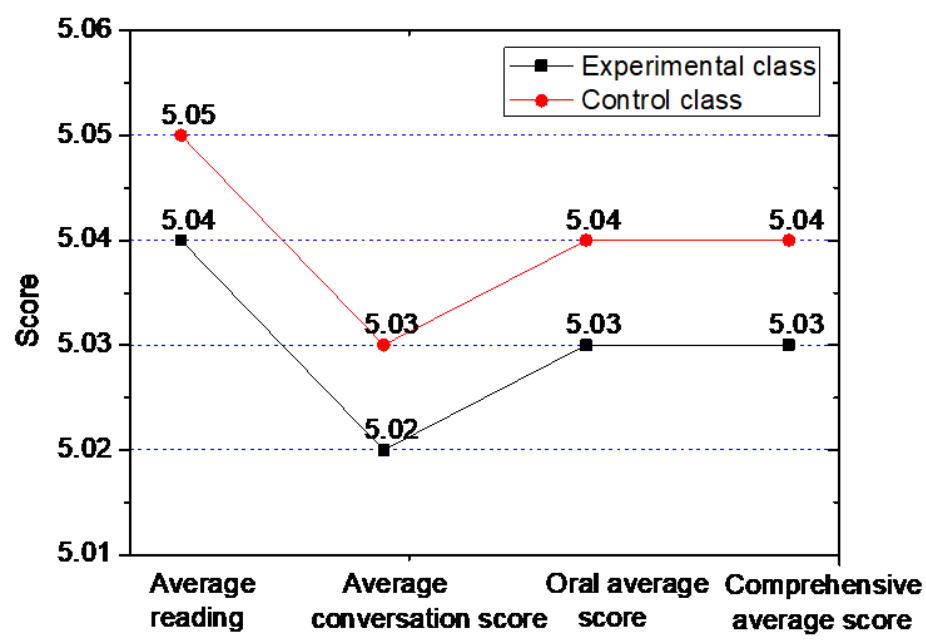

Fig. 7. Evaluation results of the English communication ability of the test group and the control group before the experiment

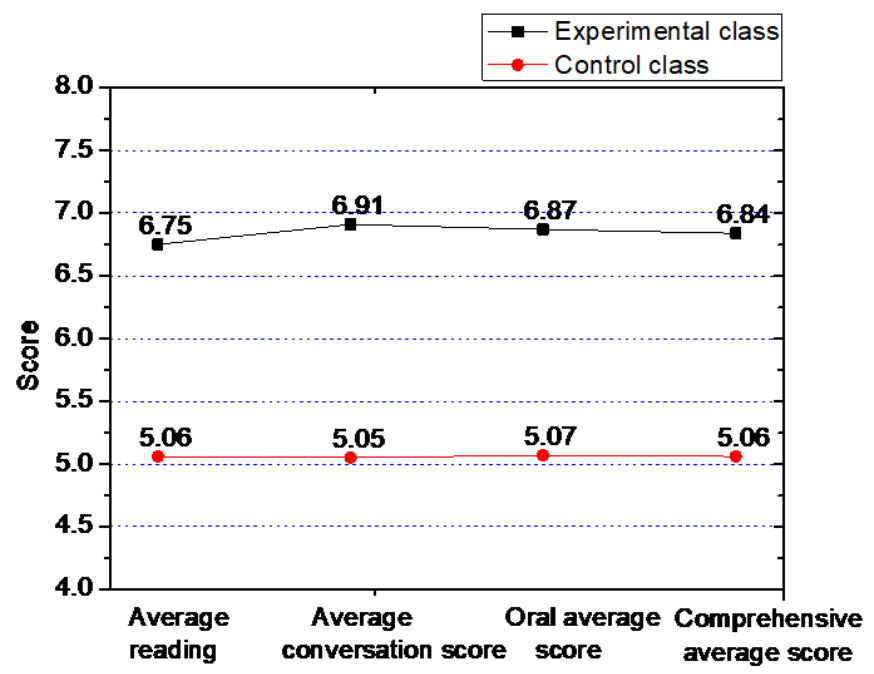

Fig. 8. Evaluation results of the English communication ability of the test group and the control group after the experiment 
Figure 8 gives the evaluation results of the English communication ability of the research objects in the test group and control group after the experiment. Figure 9 shows the evaluation results of the English communication ability of the test group before and after the experiment. According to the figure, after the experiment, the average scores and the comprehensive average scores of the test group in English dialogue, English oral composition, and English material reading are all significantly higher than those of the control group, and the scores of the test group after the experiment are also significantly higher than the scores of the test group before the experiment, to a certain extent, this verified that the e-schoolbag-based virtual scene English teaching mode had a significant impact on improving the teaching effect of English courses and it also had a positive promotive effect on improving students' English communication ability.

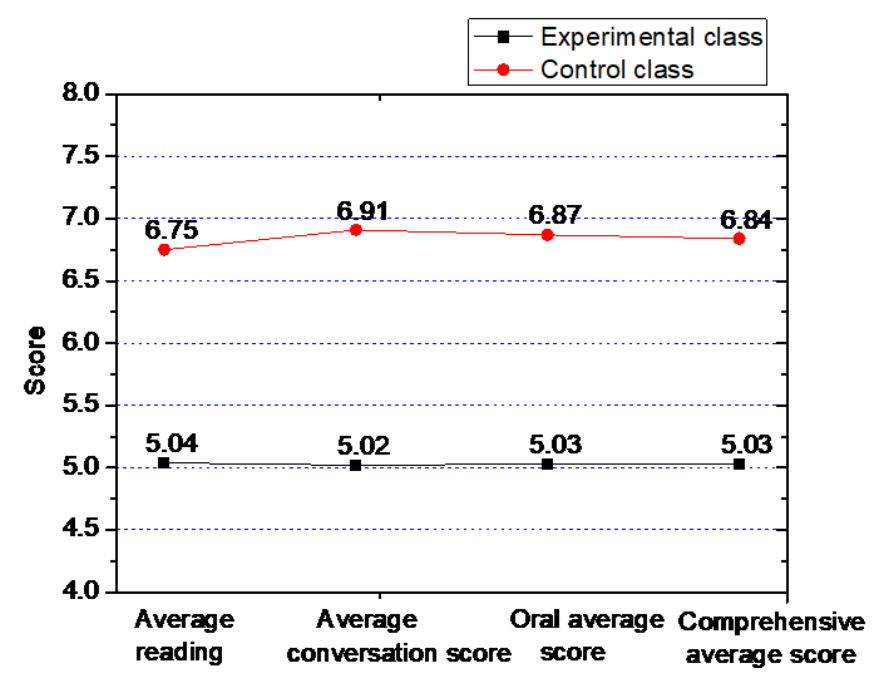

Fig. 9. Evaluation results of the English communication ability of the test group before and after the experiment

Questionnaire survey and interview results of the test group: By the end of the semester, the test group's satisfaction with the e-schoolbag-based virtual scene teaching mode was investigated using questionnaires.

Figure 10 shows the survey results on whether the respondents are satisfied with the e-schoolbag-based virtual scene teaching mode, according to the figure, students who are very satisfied and satisfied accounted for $21 \%$ and $47 \%$, respectively, and students who have an average satisfaction accounted for $28 \%$, indicating that most of them approve the proposed teaching mode. After analyzing the interview results, we found that, students generally think that the proposed teaching mode had made the teaching contents more vivid, this new teaching method had increased their interest in English learning, and enhanced the student-teacher communication and the collaborative learning of students. At the same time, the designed virtual scenes provided students with more real scenarios to practice their oral English, the man-machine dia- 
logues encourage students and make them dare to speak in English, the e-schoolbag can correct their pronunciation, and some virtual dialogue scenes and games also increased the fun of oral English training. However, still, $4 \%$ of the students expressed dissatisfaction with the e-schoolbag-based virtual scene English teaching mode, through further analysis, we found that some of these students are not interested in English learning, their English scores are very poor, and they are not interested in any teaching method at all; moreover, some of them have poor ability in autonomous learning, they believe this teaching mode has increased their learning burden, and it is not as convenient as the classroom lectures given by teachers.

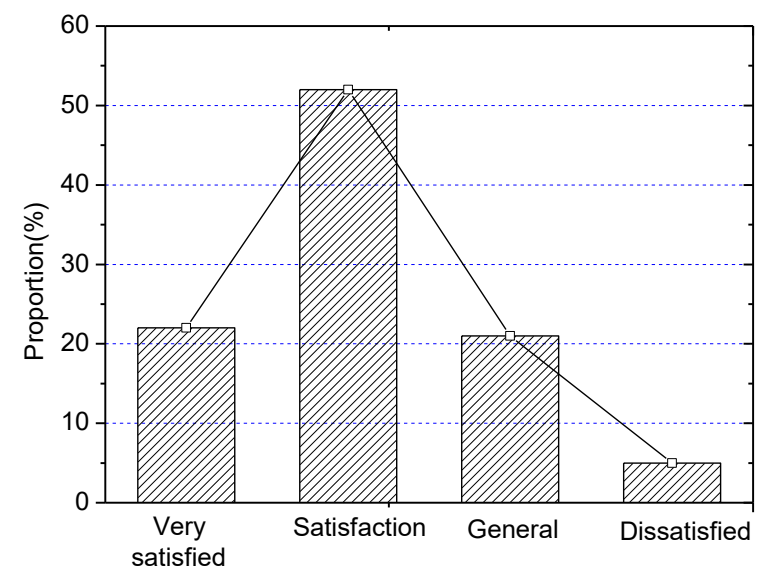

Fig. 10.Survey results on respondents' satisfaction with the e-schoolbag-based virtual scene teaching mode

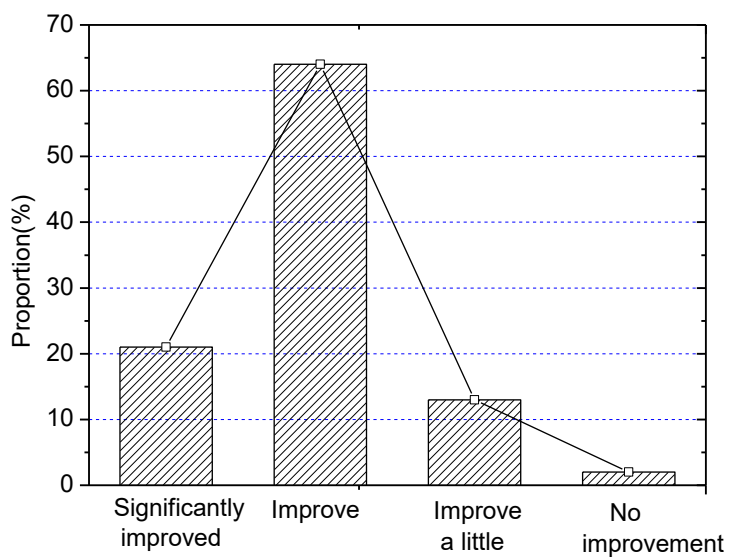

Fig. 11.Survey results on whether the e-schoolbag-based virtual scene English teaching mode has improved the respondents' English communication ability 
Figure 11 shows the survey results on whether the e-schoolbag-based virtual scene English teaching mode has improved the respondents' English communication ability. According to the figure, only $2 \%$ of the students think that their English communication ability has not been improved, and the rest of them think their English communication ability has been improved to varying degrees.

\section{Conclusion}

This paper applied the e-schoolbag technology to create virtual scenes that seamlessly connect with the real-life language speaking scenarios, and researched the impact of the proposed e-schoolbag-based teaching mode on the improvement of students' English communication ability. The specific conclusions are:

1. Based on the design ideas and principles of the virtual scenes based on eschoolbag, this paper created an e-schoolbag model with four main function modules, and the designed virtual scenes can connect with the actual language environment scenarios seamlessly.

2. The survey results on students' English communication ability showed that there are a few problems with current English teaching such as the lack of diverse teaching methods, the boring teaching contents, and the overemphasis on examination; moreover, due to the lack of a suitable language environment, current students' English communication ability is worrisome.

3. Based on the survey results and the characteristics of the e-schoolbag technology, this study proposed an e-schoolbag-based virtual scene English teaching mode.

4. This study employed comparative analysis to study the impact of the proposed teaching mode on the improvement of students' English communication ability, and the research results suggested that the e-schoolbag-based virtual scene English teaching mode can create a good language environment for students to communicate in English, it stimulated their interest in English communication, and significantly improved their ability in English communication.

\section{$5 \quad$ References}

[1] Kern, R. (2006). Perspectives on technology in learning and teaching languages. TESOL Quarterly, 40(1): 183-210. https://doi.org/10.2307/40264516

[2] Margerum-Leys, J., Marx, R.W. (2002). Teacher knowledge of educational technology: A case study of student/mentor teacher pairs. Journal of Educational Computing Research, 26(4): 427-462. https://doi.org/10.2190/jxbr-2g0g-1e4t-7t4m

[3] Chang, C.C., Warden, C.A., Liang, C., Chou, P.N. (2018). Performance, cognitive load, and behaviour of technology - assisted English listening learning: From CALL to MALL. Journal of Computer Assisted Learning, 34(2): 105-114. https://doi.org/10.1111/jcal.12218

[4] Cutrim, E.S. (2008). Using a voting system in conjunction with interactive whiteboard technology to enhance learning in the English language classroom. Computers \& education, 50(1): 338-356. https://doi.org/10.1016/j.compedu.2006.07.001 
[5] Ferriman, N. (2013). The impact of blended e-learning on undergraduate academic essay writing in English (L2). Computers \& Education, 60(1): 243-253. https://doi.org/10. 1016/j.compedu.2012.07.008

[6] Yang, M.T., Liao, W.C. (2014). Computer-assisted culture learning in an online augmented reality environment based on free-hand gesture interaction. IEEE Transactions on Learning Technologies, 7(2): 107-117. https://doi.org/10.1109/tlt.2014.2307297

[7] Johannesen, M., Erstad, O., Habib, L. (2012). Virtual learning environments as sociomaterial agents in the network of teaching practice. Computers \& Education, 59(2): 785792. https://doi.org/10.1016/j.compedu.2012.03.023

[8] Bayne, S. (2008). Higher education as a visual practice: seeing through the virtual learning environment. Teaching in Higher Education, 13(4): 395-410. https://doi.org/10.1080/1356 2510802169665

[9] Gilmore, S., Warren, S. (2007). Themed article: Emotion online: Experiences of teaching in a virtual learning environment. Human Relations, 60(4): 581-608. https://doi.org/10. $\underline{1177 / 0018726707078351}$

[10] Reiners, T., Voss, S. (2004). Teaching meta - heuristics within virtual learning environments. International Transactions in Operational Research, 11(2): 225-238. https://doi.org/ $\underline{10.1111 / \mathrm{j} .1475-3995.2004 .00454 . \mathrm{x}}$

[11] Wang, P., Qiao, S. (2020). Emerging Applications of Blockchain Technology on a Virtual Platform for English Teaching and Learning. Wireless Communications and Mobile Computing, 2020(2): 1-10. https://doi.org/10.1155/2020/6623466

[12] Woodfield, B.F., Catlin, H.R., Waddoups, G.L., Moore, M.S., Swan, R., Allen, R., Bodily, G. (2004). The virtual ChemLab project: a realistic and sophisticated simulation of inorganic qualitative analysis. Journal of Chemical Education, 81(11): 1672. https://doi.org/10. 1021/ed081p1672

[13] Rebolj, D., Menzel, K., Dinevski, D. (2008). A virtual classroom for information technology in construction. Computer Applications in Engineering Education, 16(2): 105-114. https://doi.org/10.1002/cae.20129

[14] Yang, J.C., Chen, C.H., Jeng, M.C. (2010). Integrating video-capture virtual reality technology into a physically interactive learning environment for English learning. Computers \& Education, 55(3): 1346-1356. https://doi.org/10.1016/j.compedu.2010.06.005

[15] Shakirova, N., Al Said, N., Konyushenko, S. (2020). The Use of Virtual Reality in GeoEducation, International Journal of Emerging Technologies in Learning, 15(20): 59-70. https://doi.org/10.3991/ijet.v15i20.15433

[16] Liu, Q., Chen, H., C. Crabbe, M.J. (2020). Interactive Study of Multimedia and Virtual Technology in Art Education, International Journal of Emerging Technologies in Learning, 16(1): 80-93. https://doi.org/10.3991/ijet.v16i01.18227

[17] Laciok, V., Bernatik, A., Lesnak, M. (2020). Experimental implementation of new technology into the area of teaching occupational safety for industry 4.0. International Journal of Safety and Security Engineering, 10(3): 403-407. https://doi.org/10.18280/ijsse.100313

[18] Batle, J., Ooi, C. R., Farouk, A., Alkhambashi, M. S., \& Abdalla, S. (2016). Global versus local quantum correlations in the Grover search algorithm. Quantum Information Processing, 15(2): 833-849. https://doi.org/10.1007/s11128-015-1174-y

[19] Farouk, A., Alahmadi, A., Ghose, S., \& Mashatan, A. (2020). Blockchain platform for industrial healthcare: Vision and future opportunities. Computer Communication, 154: 223235. https://doi.org/10.1016/j.comcom.2020.02.058 


\section{$6 \quad$ Author}

Lingling Hu was born on June 5, 1983 in Zhengzhou City, Henan Province, China. She received her B.A in English from Army Academy of Air Defense in 2005 and M.A. in Linguistics and Applied Linguistics from Capital Normal University in 2010. She started her teaching career in 2005 in Zhengzhou Normal University. Since teaching, she has authored more than 10 papers in English teaching and compiled a number of teaching materials. zzmail20@163.com.

Article submitted 2021-04-17. Resubmitted 2021-06-01. Final acceptance 2021-06-02. Final version published as submitted by the authors. 